\title{
The Mosques of Harar. An Archaeological and Historical Study
}

Timothy Insoll (1) and Ahmed Zekaria (2)

(1) Corresponding Author. Institute of Arab and Islamic Studies, University of Exeter, UK

E-mail: T.Insoll@,Exeter.ac.uk

(2) Institute of Ethiopian Studies, P.O. Box 1176, Addis Ababa University, Ethiopia

E-mail: $\underline{\text { Ahmedzq@yahoo.com }}$

\begin{abstract}
The mosques of Harar have been the focus of some architectural and historical study but not archaeological investigation. This was redressed through excavation of six mosques in the city, the results of which are presented. These were identified from existing historical research as significant in the Islamization of Harar. Consensus on either the date or processes of Islamization does not exist. The partial history of the mosques investigated - Aw Abdal, Aw Abadir, Aw Meshad, Din Agobera, Fehkredin, Jami - is based on only a few sources. The results of the excavations provide insights into the Islamization of Harar and supplement the limited historical sources. The six radiocarbon dates obtained indicate a varied mosque chronology spanning the late $15^{\text {th }}$ and early $20^{\text {th }}$ centuries AD. Evidence indicative of the use of mosques for educational purposes, local practices such as animal sacrifice and child burial near the mihrab, and for extensive mosque rebuilding, alteration and remodelling was found. Comparable mosques in Djibouti, Somaliland, and elsewhere in Ethiopia are considered. It is concluded that all the Harari mosques investigated post-date the late $15^{\text {th }}$ century and that the city also dates from this era and was linked with the establishment of Harar as the capital of Adal. Prior to this the Hararis, likely in the form of the legendary Harla, were elsewhere, possibly at Harlaa and other sites in the eastern Harar Plateau and Chercher Mountains.
\end{abstract}

Key Words. Mosques, Harar, Archaeology, History, Islamization 


\section{Introduction}

The city of Harar is located in eastern Ethiopia and is capital of the Harari People's National Regional State (INSERT Figure 1). Harar is an important Islamic centre and assumed this role possibly in the 16th century $\mathrm{AD}$ (all dates are $\mathrm{AD} / \mathrm{CE}$ unless otherwise stated), when archaeology indicates that the city appears to have been founded after the abandonment, for reasons unknown, of other Muslim urban centres such as Harlaa, $35 \mathrm{~km}$ northwest (Insoll 2017). Potentially, the Harari are the descendants of the legendary Harla, the occupants of Harlaa and other sites in the region. The historical city of Harar is contained within the djugel. This is a wall of $3348 \mathrm{~m}$ circumference, built of locally quarried calcareous tuff (Hashi stone) mortared with mud and wooden reinforcements (Ahmed 1990: 321; Zekaria 1997: 18). Entered by five gates, each is associated with a corresponding quarter, Asmaddinbari, Assumbari, Argobbari, Suqutatbari, and Badribari (Zekaria 1979: 22). In total, the old city encompasses an area of c. 1000 x 800 m (Horton 1994: 195). Harar was economically important as it connected the eastern highlands in which it is situated with the arid lowlands and Gulf of Aden (Wilding 1980). The city was located on a trade route running east to the Red Sea ports of Zeyla and Berbera (Insoll 2003), and minted its own coinage, probably from the $16^{\text {th }}$ century (cf. Zekaria 1991).

Prior to 2014, archaeological research in Harar had been minimal (cf. Insoll 2003), comprising a single unpublished survey (Tesfaye 2011), with emphasis instead placed upon Harari architecture and material culture such as manuscripts (e.g. Cerulli 1971; Wilding 1976; Waldron 1978; Hecht 1982; Drewes 1983; Pankhurst 1987; Santelli 2008). In 2014 test excavations aimed at assessing the origins of the city were completed in four areas; Gei Hamburti (HAM 14 [A]), the Amir Nur Shrine (AMNUR 14 [A]), Shagni Toya (SHA 14 [A]), and an Amir's Palace (PAL 14 [A]) (Insoll et al. 2014; Insoll 2017) (INSERT Figure 2). The results of these excavations were previously described in the Journal of Islamic Archaeology (Insoll 2017).

Following a unique opportunity offered by the Harar Cultural Bureau six mosques were made the focus of excavation in 2018 (INSERT Table 1; Figure 2). The mosques archaeologically investigated were identified as significant in the Islamization of Harar from the historical research of Zekaria (1979) where they were recognized as the earliest in the city. The excavations were completed as part of the European Research Council funded project, "Becoming Muslim: Conversion to Islam and Islamization in Eastern Ethiopia" (ERC-AdG2015 694254-BM) for which Timothy Insoll is Principal Investigator (cf. Insoll in preparation; Insoll et al. 2016, 2017). The 2018 fieldwork constitutes the only archaeological excavation of mosques to date in the city and because of the sensitive nature of the sites is unlikely to be repeated.

\section{The Islamization of Harar}

The origins of Harar are the subject of debate, and the history of the city has been presented in detail (cf. Insoll 2017). Not considered was the Islamization of Harar and consensus on this does not exist (Zekaria 2003: 21). The earliest claim is based on an unspecified "Arabic document" stating that "Islam reached Harar during the life time of the Prophet Muhammad, PBUH", and this was via a visit to the city by "Uthman bin Affan and his wife Ruqiya bint Muhammad who visited Harar in 615, delivered the message of Islam and "stayed for 4 
months" (Harari People Regional State 2015: 237). In contrast, Braukämper (2004: 107) suggests Islamization was later and occurred from the $10^{\text {th }} / 11^{\text {th }}$ centuries. He further notes (ibid: 109) that when the Yemeni Sufi Shaikh Abadir reached Harar accompanied by a retinue of 405 Shaikhs, probably in the early $13^{\text {th }}$ century, the local people were already Muslim. Thus, Abadir appears not to have been instrumental in the Islamization of Harar (cf. Trimingham 1952: 250), but rather "acted for a strengthening of the institutional framework of religion" (Braukämper 2004: 109).

Certainly, by the early $16^{\text {th }}$ century Harar was Islamized and it became the capital of Adal in 1520 (Santelli 2008: 625), with political importance as the powerbase of Ahmad Gragn (b. 1506) in the jihads he led against Christian Ethiopia (cf. Erlich 1994; Stenhouse 2003). Following the death of Imam Ahmad in 1543 (Braukämper 2004: 31) Nur b. al-Mujahid became Emir and is credited with building the walls of Harar (Caulk 1977: 371). Adal declined following the invasion of the Harar region by non-Muslim Oromo beginning in 1567 (Santelli 2008: 626), but the city survived as an independent Islamic emirate because of its defensive walls (Braukämper 2004: 32). This is also the start of the historical 'Dark Age' of Harar with the period between the establishment of the autonomous Emirate dynasty by Amir Ali ibn Dawd in 1647 and the visit to the city by Sir Richard Burton in 1854 described by Wagner (1974: 214) as when "we know nearly nothing about the town". However, this was not a period of total decline for it was then that "an entire body of religious literature" was completed that "was to profoundly anchor the practice of Quranic obligations and the cult of certain local saints" (Santelli 2008: 626). Harar was to develop the characteristics of Islamic practice and belief that remain today, with the Shafi school becoming dominant, probably in the early $19^{\text {th }}$ century, and replacing the Hanafi school. A change due to either differences in marriage contracts or the payment of zekat (cf. Zekaria 1979: 13-14). It was also during this period that Harar served as a conduit for the diffusion of Islam to the surrounding Oromo population (Caulk 1977: 372-373), notably during a significant Islamization campaign initiated during the reign of Amir Muhammad (1272/1856 to 1291/1875) when mosques were built at Mojo and Goru Kutumba, for example (Zekaria 1979: 9).

\section{History and Features of the Mosques of Harar}

The unpublished handwritten BA dissertation by Zekaria (1979) provides the most comprehensive historical documentation on the mosques of Harar. Because of its importance and inaccessibility, it is drawn upon extensively here. Previous studies are limited and mentions of the mosques include those by Burton (1894: 4), who refers to the city as abounding in mosques, "plain buildings without minarets", as well as those of Cerulli (1971: 405) and Paulitschke (1888: 206-207). Subsequent research has also been restricted and exceptions include a short summary of Harar mosque architecture provided by Horton (1994: 196-197) that draws on Zekaria (1979), another by Santelli (2008: 631-632), and references to the mosques in guidebooks, notably Chiari (2015: 38-40). A comprehensive map of the mosque locations has also been completed by the University of Rome La Sapienza and the Harari People's National Regional State (CIRPS 2003).

In total, 88 mosques were extant in Harar in 1979, with 82 inside the walled city, and six outside (Zekaria 1979). This figure appears to have remained constant with 82 mosques also recorded within the city walls by the Interuniversity Research Center for Sustainable Development (CIRPS) at the University of Rome La Sapienza', and the Harari People's National Regional State (CIRPS 2003). The number of mosques is more or less equally distributed in each of the 
five city quarters with about 17 mosques each. The five city quarters were subdivided into toyach, "neighbourhoods", with more than sixty of these named after either saints or the business activity of the area (Zekaria 1979: 22). These were then further divided into lazims which were also often named after mosques (Ahmed 1990: 325). Additionally, Harar contains a large number of saint's shrines distinct from mosques, leading to its alternative name as Madinat al-Awliya or 'City of Saints' (Gibb 2000: 25). The precise number of these shrines is not known (Zekaria 2003: 19), though suggestions have been made, with a total of 103 shrines provided by Santelli (2008: 631), and 107 Saints names given by Wagner (1973; cf. Braukämper 2004: 113), or the figure of 272 saints names recorded by Gibb (2000: 26), the latter including important female saints such as $\overline{\mathrm{A}} \mathrm{i}$ "Abīda, the "mother of Harar" (Gibb 2000: 36). Mosques can also be named through their association with Saints and Shaikhs (Muslim scholars and notables) or the neighbourhood they are located in. The literal meaning of " $A w$ " or "âwach is "father", and is also the common term for "saint" in Harari (Gibb 2000: 27; Zekaria 2003: 23-24) and is used in the names of mosques that refer to saints. It is also apparent that some mosques have lost their original names and have been assigned new ones (Zekaria 1979: 22).

Mosques had both a religious and social function in Harar. In Harari tradition, the mosque was where all male neighbourhood members would congregate at least once a day to pray whilst women generally prayed at home, though this has begun to alter with the construction of partitioned areas in some mosques for women to use. Mosques also served as places for Islamic learning where lessons would include Tafsir or interpretation of the Quran, the principles of Islam, Arabic language, and jurisprudence. This was facilitated by the role of Harar as a centre for learned men, Ulema, and in which a local calligraphic tradition in Arabic or in the Harari language using Arabic script developed. Notable examples of such texts include the Fathu Rahman and Mustafa written respectively in Arabic and Harari by Sheikh Hashim bin AbdulAziz al Harari (d.1197/1783-4), an individual whose mosque and shrine are found in the Argoberi quarter of the city (Zekaria 1979: 10-12,33). More recently, such teaching has largely devolved to the Jami Mosque. Every mosque also possessed a Waqf property such as a piece of farm land or house for lease given to it by an interested individual or the builder of the mosque. These endowments were traditionally managed by the Muezzin, and served to finance the construction and maintenance of the mosques and associated institutions such as schools (Zekaria 1979: 32-37).

There are a variety of traditional architectural features found and materials used in the mosques of Harar that survive to different degrees. Walls were built of limestone and granite using mud mortar mixed from local red (Qeh Afer) and black (Guguba) soil. Traditionally, the mortar was prepared and then left to strengthen for three to four months before being used. The stone was quarried in the region from, for example, the Aw Hakim Hills. Locally sourced juniper wood was the main building timber because of its ubiquity and resistance to termites. Construction techniques were essentially the same for mosques and secular buildings. Limestone walls were erected on two rows of granite foundations bedded in trenches of $50-80 \mathrm{~cm}$ depth and $50-60 \mathrm{~cm}$ width. Granite was used up to floor level because of its load-bearing properties and limestone above due to perceptions about its resistance to earthquakes and adhesive effect in cementing mud mortar. Walls were built to an average height of $4 \mathrm{~m}$ and horizontal layers of wooden planks added at every metre above ground to prevent cracking. Any small remaining gaps in the walls were then filled with stones and mortar. The interior walls were then plastered with guguba mortar and finished with lime whitewash (Zekaria 1979: 39-40). 
Roofs were flat, made of juniper rafters infilled with small stones and mortar with a layer of grass or matting on top, and finished with a final coating of mud mortar. The roof was supported on rafters running to a beam placed on top of pillars. The average length of building timber was five metres which determined pillar spacing. Rafters were placed between the beam and the parallel walls and were fixed in place using a mixture of mud mortar and small stones applied between each rafter. Smaller lengths of wood (kebel) in Harari, were fixed across the rafters to complete the wooden roof framework. Two carved wooden semi-circular rain spouts projecting some $20 \mathrm{~cm}$ from the wall would provide drainage but have more recently been replaced by pieces of iron sheet serving the same function. Corrugated iron roofs have now tended to replace the traditional roof covering as they require much less maintenance (Zekaria 1979: 40-42).

The architectural features of the mosques appear to have remained unchanged for a considerable period of time, except, possibly, for the introduction of tower minarets that were added to, for example, the Jami Mosque and the Aw Meshad Mosque (Zekaria 1979: 44). Mosques were rectangular in shape and generally small in size (Zekaria 1979: 43), varying between $24 \mathrm{~m}^{2}$ and $35 \mathrm{~m}^{2}$ (Santelli 2008: 631). Larger numbers of smaller mosques, a feature of Harar, were believed "to strengthen the social fabric of the society by developing a strong intimacy within a neighbourhood" (Zekaria 1979: 43). The sahn or courtyard in front that gave access to the mosque was usually walled and with a single access door. These were kept clean and could be used as an extension of the prayer area. The sahn was also frequently used to grow medicinal plants and fruits particularly pomegranate (Punica granatum), believed to be efficacious for curing stomach complaints (Zekaria 1979: 36).

Within the main prayer hall, mihrab recesses tended to be simple and were generally accompanied by four other niches, the two left and right of the mihrab for storing books, and the additional two for storing other mosque items. The traditional form of minaret was of the staircase type attached to the southern wall of the prayer hall. This could be provided with a box-like covering to protect the muezzin from the elements (INSERT Figure 3). Minbars were rare and until 1979 only one was found in the Jami Mosque (Zekaria 1979: 46). Ablutions facilities and toilets were generally not provided in the Harar mosques, with the exception of a hand-filled well at the Jami Mosque, and likely reflected the scarcity of water until the arrival of a piped supply to the city from Lake Haramaya (cf. Hecht 1982: 73), approximately $20 \mathrm{~km}$ west of the city. Attached to the main mosque building was sometimes a side room, a zawiya, used as a dormitory, with a nadaba, a raised platform for eating and sleeping, a small circular opening in the ceiling to let in light, and three or four wall niches (Zekaria 1979: 48-49). This type of room is discussed further below.

The partial history of the six mosques can be reconstructed as follows:

i. Aw Abdel Mosque. This mosque now serves as the funerary mosque for Harar and is situated outside the djugel, east of the city and adjacent to the cemetery. According to a list of rulers of Harar it appears to be linked with Amir Abadal/Abdel, the tenth Amir who reigned between 670-690/1272-1292 (Zekaria 1979: 27). Ahmad (1990: 326) describes Aw Abdel as formerly a threshing ground used during the annual sorghum harvest and as the place for prayers during Id ad-Fitr and Id al-Adha.

ii. Aw Abadir Mosque. According to tradition this mosque was built by Abadir in the $12^{\text {th }} /$ early $13^{\text {th }}$ century (Zekaria 1979: 28). 
iii. Aw Meshad Mosque. This mosque is believed to be one of the oldest in Harar, pre-dating Abadir's arrival in the city and was where Abadir prayed in the early $13^{\text {th }}$ century (Zekaria 1979: 23). Tradition states Aw Meshad was from Iran and came to Harar "with one of the three groups of Iranian sheikhs who left their country to preach Islam respectively in Harar, Yemen, and Zanzibar" (Chiari 2015: 176-177).

iv. Din Agobera Mosque. This mosque, also referred to as Din Agobara (CIRPS 2003) or Dini Gobena (Zakaria 1979: 27) is both larger than the average mosque at $90 \mathrm{~m}^{2}$ and is partitioned for women, as such it was believed to have been formerly used for Friday prayers, but in an unspecified period. Locally, the mosque is claimed to have been built "before seven hundred years" (Zekaria 1979: 47), and according to tradition the rock it is built upon is "where the first conversion to Islam took place" (Foucher 1994: 71).

v. Fehkredin Mosque. According to tradition, Fehkredin Yunis was the son of the Sherif of Mecca who came to Harar with the builders of the mosque in the $16^{\text {th }}$ century (Zekaria 1979: 26). The situation of the mosque appears to be particularly significant as it is located in Gei Hamburti (Figure 2), known locally as the 'navel' of the city (A. Sheriff pers. comm. 18/7/14), suggesting it is of importance in the the foundation and development of Harar (Insoll 2017: 194). This is a large rock in the centre of Harar (Zekaria 1979: 26), and is described by Sir Richard Burton (1894: 40) as "the historic rock upon which Saint Nur held converse with the prophet Khizr".

vi. Jami Mosque. The Jami or Friday/Congregational mosque is believed in local tradition to also be early in date, and according to an unpublished chart compiled from unknown sources by Ahmed Shami in the 1970s was built with one tower minaret in 613/1216. The second minaret was apparently added later in the $16^{\text {th }}$ century during the reign of Ahmed Gragn, whose gravestone is included in the prayer hall to the right of the minbar. An inscription on the wooden minbar indicates that this was constructed in 1175/1761, i.e. during the reign of Amir Ahmed (Zekaria 1979: 25-26). An alternative date of 1177/1763-64 is given by Chiari (2015: 128). Burton (1894: 13) described the mosque as "a long barn of poverty-stricken appearance" with two minarets of "truncated conoid shape" one of which had recently fallen and had been rebuilt. The mosque was expanded by Amir Abdullahi in the 1880s who constructed a new Qibla wall and extended the area of the Mosque by $200 \mathrm{~m}^{2}$ giving it an unusual T shape (Zekaria 1979: 46), meaning that the "original arrangement of the mihrab is not known" (Horton 1994: 197). It is possibly this phase of alteration that is recorded in the image on the left in Figure 12, discussed below. The Jami Mosque was further altered during the period of Italian occupation between 1936 and 1941 with the addition of a water pool in the courtyard and in 1980 it was extensively remodeled with water taps provided in the courtyard and the addition of an upper floor (Chiari 2015: 128-129). The plan provided in Figure 4 (INSERT Figure 4) predates this last phase of re-modelling.

\section{Harar Mosque Excavations}

Eight excavation units were completed at the six mosque sites in Harar (Table 1, Figure 2). Permission to excavate was obtained from the mosque authorities by the Cultural Bureau in Harar. All deposits were sieved through a $3 \mathrm{~mm}$ mesh unless otherwise indicated. 


\section{i. Aw Abdel Mosque - ABD 18 (A)}

The excavation unit was directly east of the mosque building in an unused area between the mosque and boundary wall (N09.30926 E042.14431 ${ }^{\circ}$ ) (Figure 2), as it was not allowed to excavate inside the mosque itself. The unit size was dictated by the narrow available area for excavation and measured approximately $120 \mathrm{~cm}$ east-west by $217 \mathrm{~cm}$ north-south. The cement layer of c. $5 \mathrm{~cm}$ depth that covered the space was broken through exposing an orange gravel fill which was removed to a variable depth of between $15-25 \mathrm{~cm}$ to create a level working surface (ABD 18 [A] 1). The next 20cm removed (ABD 18 [A] 2) indicated a change to a dark brown organic soil containing some charcoal. This continued in the succeeding $20 \mathrm{~cm}$ and contained no archaeological material (ABD 18 [A] 3). The same dark brown organic soil but with some flecks of charcoal and roots present was found in the subsequent $20 \mathrm{~cm}$ level (ABD 18 [A] 4).

The next $30 \mathrm{~cm}$ of deposit (ABD 18 [A] 5) was the same but with an increase in stones at the base of the level. The excavation area was also reduced to leave a step for access in the southern end of the unit of maximum $60 \mathrm{~cm}$ length north-south and $120 \mathrm{~cm}$ width east-west. The final $20 \mathrm{~cm}$ removed (ABD 18 [A] 6) indicated a change from the brown organic soil back to an orange gravel which was just above the natural bedrock at the base of the unit. An Accelerator Mass Spectrometry (AMS) radiocarbon date was obtained from charcoal from this level of the early $18^{\text {th }}$ to early $19^{\text {th }}$ centuries (INSERT Table 2). Excavation was halted at the bedrock at a maximum depth of $130 \mathrm{~cm}$ from the ground surface in the north-east corner of the unit and $135 \mathrm{~cm}$ deep at the south-west corner. The eastern external stone-built wall of the mosque compound was found to be constructed directly onto the bedrock (INSERT Figure 5). The unit was then backfilled and the cement surface reinstated.

The area excavated was connected with the mosque but contained no structural features except for the boundary wall. The brown organic fill was likely moved here during construction of the mosque, the floor of which was slightly lower $(\mathrm{c} .50 \mathrm{~cm})$ than the ground level of the excavated area. The absence of plastic or other indicators of modern contamination in this fill suggests that this was not recently deposited and had been sealed under the cement surface at an unknown date, but unlikely to exceed 80 years, i.e. the first date of introduction of cement to the region after the establishment of the cement factory at Dire Dawa in 1936 (web reference 1).

\section{ii. Aw Abadir Mosque - AWAB 18 (A)}

Excavation was completed on the path inside the gate to a housing compound belonging to the Shaikh in charge of the Aw Abadir shrine complex (N09.30584 E042.13946 ${ }^{\circ}$ ) inside and close to the djugel in the southeast of the city (Figure 2). The unit was west of and immediately adjacent to the entrance to the Aw Abadir Mosque located on the opposite side of the lane from the Aw Abadir shrine, both locations that it was not possible to excavate directly inside as permission was not given. The size of the unit was dictated by the confines of the path and the necessity of leaving access to the housing compound. It measured $2 \mathrm{~m}$ east-west by $150 \mathrm{~cm}$ north-south.

The top $20 \mathrm{~cm}$ removed was of compacted brown soil and plaster rubble (AWAB 18 [A] 1). This indicated the existence of two pits, one of $49 \mathrm{~cm}$ width and a maximum depth of $30 \mathrm{~cm}$ and the other larger pit of $110 \mathrm{~cm}$ north-south by $100 \mathrm{~cm}$ east-west and with a maximum depth of $160 \mathrm{~cm}$. Both these pits contained modern material and thus were emptied as part of the same context number with the smaller found to be full of faunal remains and the larger plaster rubble. 
Following demarcation and emptying of the pits (INSERT Figure 6) the deposits of which were not sieved because of the modern material they contained, $10 \mathrm{~cm}$ of hard orange brown clay like matrix, possibly the remains of a surface for the path or the floor of a building now destroyed, was removed (AWAB 18 [A] 2). This continued in the subsequent $10 \mathrm{~cm}$ (AWAB 18 [A] 3) and contained some potsherds and bone fragments. The consistency of this deposit became harder and redder, more like a laterite crust, and had to be removed using a pick in the next $10 \mathrm{~cm}$ level (AWAB 18 [A] 4). At the base of this a softer brown earth deposit was encountered. Further hard compacted red brown earth floor or path surface deposits were found in the subsequent $10 \mathrm{~cm}$ (AWAB 18 [A] 5). In the next 10cm removed (AWAB 18 [A] 6), a hearth was recorded in the western part of the unit. An AMS date was obtained from charcoal from this level of the mid- $18^{\text {th }}$ to early $19^{\text {th }}$ centuries (Table 2). An orange laterite gravel, the natural material, was found at the base of AWAB 18 (A) 6. Excavation was stopped at a depth of between $60-70 \mathrm{~cm}$, except for the cutting back of the western face of the large pit to check that the natural had been reached. The unit was backfilled.

The absence of structures and the presence of the pits, hearth, and compacted floor/path surfaces suggests that this area might always have had a utilitarian function for activities that would not be undertaken in the mosque or shrine itself such as rubbish burial and, potentially, the processing and cooking of animal remains. It is possible that this formed part of a kitchen with a grass roof cover. These huts, gambisa or tukul, were common in Harar until approximately 50 years ago. The existence of the faunal remains in the pit was explained by the local workmen and the shrine attendants as the result of feasting at the complex particularly during the Mawlid festival to celebrate the Birthday of the Prophet Muhammad in the $12^{\text {th }}$ of Rabi' al-Awwal (cf. Gibb 2000: 29; Harari People Regional State 2015: 253), though it could also occur at any time of year. As part of this, the shrine visitor would bring a sheep or cow and this would be slaughtered at Aw Abadir. After eating the meat, the bones would be buried in a pit or given to hyenas (EXPAND).

\section{iii. Aw Meshad Mosque - AWM 18 (A) and (B)}

The third site excavated was the Aw Meshad Mosque located a couple of hundred metres outside the djugel to the south-west of the city (Figure 2). Two units were excavated, one in the courtyard outside the mosque (AWM 18 [A]), the deposits from which were not sieved, and one in a zawiya that formed part of the current mosque structure (AWM 18 [B]) the deposits from which were sieved.

AWM 18 (A), a unit of 2 by $2 \mathrm{~m}$, was located in an open stony area immediately west of the cement platform giving access to the mosque (N09.30826 ${ }^{\circ}$ E042.13179 $)$. The top deposit of loose stones gave way to a dark brown matrix filled with modern rubbish such as plastic bottles, electrical cable and scraps of fabric (AWM 18 [A] 1). Large stones were also found as depth increased, i.e. fragments of discarded building material, and a tree stump was present in the north-east corner of the unit. The level was changed at $45 \mathrm{~cm}$ from ground surface, and AWM 18 (A) 2 excavated to a depth of $100 \mathrm{~cm}$. The deposits were composed of a rich brown organic silty clay mixed with sand with some stones of c. $40 \times 40 \mathrm{~cm}$ and numerous smaller stones present as well as the continuation of plastic and modern glass inclusions. A section of deposits measuring c. $70 \mathrm{~cm}$ by $70 \mathrm{~cm}$ in the north-east of the unit were left in-situ as they were supporting a post for the verandah. 
In the subsequent level (AWM 18 [A] 3), the quantity of modern plastic inclusions diminished and were restricted to the northern end of the trench where they had been transported down by root action. Several large boulders were found bisecting the trench diagonally south-west to north-east (INSERT Figure 7). These were unworked and immovable suggesting they were natural. The bedrock was reached at a maximum depth of $170 \mathrm{~cm}$. Because of the modern contamination and the lack of evidence for intentional anthropogenic action other than rubbish dumping, the unit was not AMS dated. It would always seem to have been exterior to the mosque.

The second unit excavated, AWM 18 (B), was a strip of $100 \mathrm{~cm}$ east-west by $200 \mathrm{~cm}$ northsouth at the far south-western end of the floor in the interior of a large rectangular low-roofed room described as a zawiya and situated on the western side of the interior mosque courtyard (N09.30826 ${ }^{\circ}$ E $042.13179^{\circ}$ ). This type of zawiya was inhabited by the Mesjid Gele, meaning "one who lives in a mosque" in Oromo. These individuals received education in the Quran, Islamic teaching and jurisprudence, and Arabic language, but this tradition of residential pupils is now extinct (Zekaria 1979: 33-34). The tradition of Iranian origin for Aw Meshad also records that the Iranian sheikhs established their Quran school at the mosque (Chiari 2015: 177).

Following surface cleaning, the top $1 \mathrm{~cm}$ thick layer of cement floor surface and $9 \mathrm{~cm}$ of cement powder beneath were removed (AWM 18 [B] 1). This gave way to a mid to light brown friable sandy silt deposit containing small stone inclusions that was excavated to a depth of $25 \mathrm{~cm}$ (AWM 18 [B] 2). A small patch (c. 40 by $50 \mathrm{~cm}$ ) of ashy charcoal deposit was found in the north-east corner of the unit. The subsequent $15 \mathrm{~cm}$ was a similar but more compact deposit containing further stone (AWM 18 [B] 3). At the base, a stone wall was recorded bisecting the unit and underneath the patch of ash and charcoal a cobbled stone surface was found. These emerging architectural features were cleaned (AWM 18 [B] 4) with a chalky white floor surface found south of the stone floor.

Excavation was next focused on the central area of the unit devoid of architectural features between the stone wall and cobbles (AWM 18 [B] 5). The same mid-brown deposit was removed to a depth of $50 \mathrm{~cm}$. A darker brown silty sand was encountered beneath this and cleaning of an additional $3 \mathrm{~cm}$ of deposit (AWM 18 [B] 6) revealed that underneath was a surface of secondary cobbles and gravel cut by an east west linear drain or gulley feature. Cleaning of this feature (AWM 18 [B] 7) indicated that it was steep sided with a concave ushaped profile. The white floor surface was next excavated (AWM 18 [B] 8) and was succeeded by a mid to dark brown deposit containing small stones that was AMS dated from charcoal to the early $19^{\text {th }}$ to early $20^{\text {th }}$ centuries (Table 2), and gave way to a gravel layer, the natural stone matrix. The area of secondary gravel next to the linear gulley in the northern part of the unit was then investigated (AWM 18 [B] 10) and a branch to the gulley running north found (Figure 7). This linked to the cobble area in the north-east corner indicating that it was a soak-way drained into by the gulley system (Figure 7). The excavation was then stopped at a maximum depth of c. $75 \mathrm{~cm}$ from the floor level of the zawiya and the unit backfilled onto plastic sheet to facilitate future excavation.

The floor of the zawiya was elevated to a height of c. $70 \mathrm{~cm}$ above the ground level of the internal mosque courtyard. This suggests that the drain was connected with the original zawiya building, since rebuilt, and the drain may have functioned as part of an ablutions system. The whole complex has evidently been much altered. The zawiya is now part of the roofed complex that also contains the mosque and minaret. The roof covering the internal courtyard that links 
these three elements was described by members of the mosque governing body as recent, but otherwise undated. Previously, the mosque, zawiya, and minaret were free-standing (Figure 7), analogous to the Aw Abdel Mosque which has the minaret separate from the mosque but lacks a zawiya (Figure 5).

\section{iv. $D I N 18(A)$}

Permission was granted to excavate a unit directly behind the mihrab of the Din Agobera mosque which is located inside the djugel in the west of the city near the Argob Bari (gate) (N09.31081 ${ }^{\circ}$ E042.14109 ${ }^{\circ}$ ) (Figure 2). The excavation was completed in a narrow space between the southern wall of the majlis (reception room) of a house and the northern wall of the mosque just west of the external bulge formed by the mihrab niche (c. $60 \mathrm{~cm}$ width by $170 \mathrm{~cm}$ length) (INSERT Figure 8). The interior of the mosque was not viable for excavation as it was completely covered with concrete or built directly onto rock outcrops.

After removal of the top $5 \mathrm{~cm}$ layer of concrete, $10 \mathrm{~cm}$ of stony brown organic soil was excavated before another $10 \mathrm{~cm}$ of concrete and associated rubble was encountered (DIN 18 [A] 1). This yielded in the north-west corner to a darker soil containing archaeological material (potsherds and bone). A similar brown soil containing some stone inclusions was then found across the unit and between 10-12 cm of this was removed (DIN 18 [A] 2). A large posthole was recorded in the north-west of the unit of $26 \mathrm{~cm}$ diameter and $10 \mathrm{~cm}$ depth with a footing stone at its base. A further $10 \mathrm{~cm}$ of the same brown stony soil was excavated (DIN 18 [A] 3). This continued in the subsequent $10 \mathrm{~cm}$ (DIN 18 [A] 4) but with a concentration of charcoal found at the western end of the unit where the deposits were looser. Some plastic bags were also found in the north-east corner. There was also a posthole extending under the edge of the trench in the south-west of the unit, $21 \mathrm{~cm}$ below the depth of this level, which was now approximately $50 \mathrm{~cm}$ in the west and $60 \mathrm{~cm}$ in the east below ground surface.

The deposit changed slightly in the subsequent $10 \mathrm{~cm}$ to a sandier but still brown organic soil (DIN 18 [A] 5). The posthole footing stone in the north-west of the unit was removed and an AMS date was obtained from charcoal found beneath the stone of the early $18^{\text {th }}$ to early $19^{\text {th }}$ centuries (Table 2). The same deposit continued in the next $10 \mathrm{~cm}$ level (DIN 18 [A] 6) but at the bottom changed to an orange gravel except in the western part of the unit where a layer of stones was revealed (Figure 8). The stones were left in place and excavation of the remainder of the unit indicated that the orange gravel layer was marginal and replaced in the next $10 \mathrm{~cm}$ by further brown organic soil containing some sand (DIN 18 [A] 7). This deposit continued in the final $10 \mathrm{~cm}$ level excavated (DIN 18 [A] 8) which reached bedrock at a depth of between $104-110 \mathrm{~cm}$ except where the stone layer had been left in-situ. The stone layer in the western end of the unit was next removed (DIN 18 [A] 9). This exposed the crania of a juvenile human burial (Figure 8). This was cleaned and three teeth removed for isotope analysis with all other human remains left undisturbed. The burial fill was a loose brown organic soil containing charcoal fragments, one of which provided an AMS date of the late $15^{\text {th }}$ to mid-1 $7^{\text {th }}$ centuries (Table 2).

The east-west orientation of the burial with the head to the east and the face to the north toward the Qibla indicated that it was Muslim. The burial was then recovered with stone slabs, the unit backfilled, and the surface rendered again with cement. The presence of the burial reflects the former practice of burying children around the mihrab in Harar. The house the excavation was completed next to has also been extended to the south in the recent past with the addition of a 
majlis to the earlier structure. This has incorporated and covered an open area that was formerly used for burial (M. Rabi pers. comm. 19/2/18).

\section{v. FAK 18 (A) and (B)}

Two units were excavated adjacent to the Fehkredin Mosque in the Gei Hamburti area of Harar in the very centre of the djugel (Figure 2). Unit FAK 18 (A) of $200 \mathrm{~cm}$ length north-south and $100 \mathrm{~cm}$ width east-west was excavated in the external courtyard of the mosque immediately west of the Saint's qubba (N09.30994 E042.13721 ${ }^{\circ}$ ). The concrete floor and the rubble beneath were first removed to a depth of $42 \mathrm{~cm}$ in the south-eastern corner and $30 \mathrm{~cm}$ in the north-western corner to create a level working surface (FAK 18 [A] 1 . The next $10 \mathrm{~cm}$ level of dark brown soil was split into two sections by a large pit deposit bisecting the unit (FAK 18 [A] 2). The first $10 \mathrm{~cm}$ of the pit deposit of brown organic soil contained ceramics and corroded iron objects such as nails (FAK 18 [A] 3). This continued in the subsequent $10 \mathrm{~cm}$ (FAK 18 [A] 4) with large quantities of bone, pottery, and iron nails present. These pit deposits then gave way to an orange laterite in the north, and red laterite in the south of the pit area. (FAK 18 [A] 5). Two postholes were found in the orange laterite of $10 \mathrm{~cm}$ and $12 \mathrm{~cm}$ diameter and $13 \mathrm{~cm}$ and $9 \mathrm{~cm}$ depth.

A further pit was demarcated in the western half of the unit. This was emptied of its contents to a maximum depth of $165 \mathrm{~cm}$ from ground surface (FAK 18 [A] 6). The contents of the pit were modern and included some plastic, as well as ceramics, recent glass, and bone. The orange laterite fill of $3-6 \mathrm{~cm}$ depth, possibly disturbed floor material, was excavated to test its depth with beneath another layer of dark brown soil containing pottery and modern glass (FAK 18 [A] 7). As all the deposits contained modern material excavation was halted outside the pit at c. $120 \mathrm{~cm}$ depth from ground surface, and in the pit at $165 \mathrm{~cm}$ (INSERT Figure 9). The unit was backfilled and a new concrete floor surface laid. The absence of any uncontaminated deposits in the unit was described as due to their removal in the 1980s and replacement with rubbish (A. Malik pers. comm. 22/2/18), presumably as a correlate of rebuilding. Because of the presence of the modern material the unit was not AMS dated. The results suggest that the mosque has been extensively re-modelled.

The second unit, FAK 18 (B), of $150 \mathrm{~cm}$ by $150 \mathrm{~cm}$ size, was excavated in an open area adjacent to the external face of the window of the picture gallery in the Abdullah Sherif Museum $\left(\mathrm{N} 09.30973^{\circ} \mathrm{E} 042.13728^{\circ}\right)$. The deposits were not sieved. The top $20 \mathrm{~cm}$ of modern rubbish filled gravel deposits was removed (FAK 18 [B] 1) and a concrete surface encountered. This was broken up and beneath this further modern construction debris was found before another concrete surface was recorded. Excavation was then terminated at a depth below the sloping ground surface of $97 \mathrm{~cm}$ on the western side and $87 \mathrm{~cm}$ on the eastern side of the unit (Figure 9). The lower concrete surface was described by an adjacent house owner as part of a flight of steps built by the Italians in the 1930s (A. Bashar pers. comm. 20/2/18).

\section{vi. JAM $18(A)$}

The final $2 \mathrm{~m}$ by $2 \mathrm{~m}$ unit excavated was immediately beside the external western side of the mihrab of the Jami Mosque (N09.31123 ${ }^{\circ}$ E042.13871 ${ }^{\circ}$ ) (Figure 2). Excavation in the mosque itself was not possible due to local restrictions. The top $20 \mathrm{~cm}$ of pale beige sandy fill containing 
modern rubbish, pieces of concrete and some stones was discarded (JAM 18 [A] 1). This gave way to a more orangey brown fill with pieces of ceramic floor tile and plastic. A deeper pit filled with the same contaminated deposit was excavated to a depth of $55 \mathrm{~cm}$ in the south of the unit. The pit was further emptied to a depth of $98 \mathrm{~cm}$ (JAM 18 [A] 2). The contents included cement sacks and plastic bags filled with rubbish. $13 \mathrm{~cm}$ of deposit was also removed across the remainder of the unit, a compact orangey brown sandy matrix containing large stones, blocks of masonry, and excrement (JAM 18 [A] 2). Further plastic was encountered at the top of the next $35 \mathrm{~cm}$ of deposits removed across the unit (JAM 18 [A] 3), excluding the pit which was left further unexcavated. This was composed of the same orange brown matrix and contained significant quantities of large stones, possibly building foundations. This ended at a depth of between $70-75 \mathrm{~cm}$ when a layer of orange gravel was found.

The orange gravel layer was excavated to a depth of $10 \mathrm{~cm}$ and sieving was started at this level (JAM 18 [A] 4) as modern contamination had ceased. The deposits appeared sterile so sieving was also stopped at the base of this level. A series of large stone blocks were recorded at a depth of $89 \mathrm{~cm}$ depth from ground surface in the northern side of the trench. This was the remains of a wall and a line of three postholes was also found on the eastern side of the trench in the next shallow $3 \mathrm{~cm}$ level of the same orange gravel deposits removed (JAM 18 [A] 5). Three stones laid into the surface of the northern side of the unit were also found. These appeared to be a feature but for an unknown purpose. After final cleaning (JAM 18 [A] 6), bedrock was encountered across the unit and excavation was halted at a maximum depth (excluding the pit) of $91 \mathrm{~cm}$ below the ground surface (INSERT Figure 10). An AMS date from charcoal was obtained from near the stone feature of the late $18^{\text {th }}$ to late $19^{\text {th }}$ centuries (Table 2). The unit was backfilled.

The modern fill and the probable stone foundation layer were likely related to a house which had stood in the same area as that excavated until it was demolished in 2017. The earlier architectural remains (wall, postholes, stone feature) relate to a previous structure likely dating to the hundred-year period represented by the AMS date between the late $18^{\text {th }}$ and late $19^{\text {th }}$ centuries and not the mosque itself.

\section{Archaeological Material from the Harar Mosque Excavations}

The archaeological material recovered from the Harar mosque excavations, excluding locally made ceramics and faunal remains, is limited in quantity (INSERT Table 3). This reflects the types of sites excavated, i.e. the surroundings of mosques and shrines, but also the comparative material impoverishment of the city previously noted archaeologically (Insoll 2017). The material is under analysis (Insoll in preparation) but initial results indicate that the locally made ceramics are of types previously recorded and of post $16^{\text {th }}$ century date (Insoll 2017: 202-206). These include black, brown, and red slipped wares, otherwise undecorated, from bowl, flask, and jar forms of various sizes, some with handles (INSERT Figure 11). Flat, simple open, and simple closed rim forms were noted.

The two sherds of Middle Eastern glazed ware and the single sherd of Far Eastern glazed ware are of types not present in the Harlaa excavations (cf. Insoll et al. 2017). This suggests they are later in date than the terminal $15^{\text {th }}$ century chronology at Harlaa. The Far Eastern sherd appears to be $18^{\text {th }}$ or $19^{\text {th }}$ century Chinese blue and white ware and from a small bowl (H. Parsons pers. comm. 26/7/18; Figure 11). The other two sherds are unidentified, but possibly of Yemeni or Egyptian origin (Figure 11). 


\section{Discussion - Mosques and the Islamization of Harar}

The archaeological data provides insights into the Islamization of Harar that supplement the limited historical sources already discussed. The AMS date from the Aw Meshad Mosque of the early $19^{\text {th }}$ to early $20^{\text {th }}$ centuries suggest that the zawiya could be a later addition to the mosque, or if integral from its foundation, that the mosque itself is comparatively late in date, or that the core of the earliest pre-Abadir mosque and zawiya referred to in tradition has disappeared. The AMS date from the Aw Abdel Mosque suggests that it was constructed or substantially remodeled sometime between the early $18^{\text {th }}$ and early $19^{\text {th }}$ centuries. The AMS date from the base of the deposits in the pit outside the Aw Abadir Mosque is suggestive that the sacrifice practices linked with mosque visitation began in the mid- $18^{\text {th }}$ to early $19^{\text {th }}$ centuries. This could reflect the development of this practice or that the mosque was either built or reconstructed at this date.

The two AMS dates from the Din Agobera mosque relate to different phases. The later (early $18^{\text {th }}$ to early $19^{\text {th }}$ centuries) is linked with an unknown ancillary structure that appears to have been erected behind the mosque probably in connection with or pre-dating the extant house in that location. The other date (late $15^{\text {th }}$ to mid- $17^{\text {th }}$ century) is the earliest from the excavations and dates the burial fill, as previously described. The presence of the burial suggests that the Din Agobera Mosque predates the burial as it was the mosque mihrab as an apex of sanctity that was the focus for burial. If the mid-point of the AMS range is taken (Table 2), this suggests the burial is $16^{\text {th }}$ century and the mosque is possibly of a similar age or slightly older. The central position of the Fehkredin Mosque in Gei Hamburti suggests it was likely significant in Islamization. However, this was not supported by the archaeological material recovered which was all recent in date. This replicated the chronology found in a unit previously excavated in this area of the city (cf. Insoll 2017: 193-194). It is likely that this mosque has been extensively rebuilt.

The AMS date of the late $18^{\text {th }}$ to late $19^{\text {th }}$ centuries obtained from adjacent to the mihrab of the Jami Mosque does not date the mosque itself but, as previously described, structures that were built up close to the mosque. The mihrab is also not from the original mosque (Zekaria 1979; Horton 1994: 197). Whether the original structure survives is unknown, but it is unlikely that this is early $13^{\text {th }}$ century in date, and it is suggested that a $16^{\text {th }}$ century foundation date is more probable based on the overall settlement chronology (Insoll 2017).

The recurrent rebuilding, alteration, renovation, and re-modelling is something that has significantly affected mosques in Harar. This is apparent in comparing the two images of the Jami Mosque in Figure 12 (INSERT Figure 12). Both are undated but are likely late $19^{\text {th }} /$ early $20^{\text {th }}$ century. In the earlier image on the bottom left, the un-plastered stone and mud mortar walls are visible and the mosque is entered through three doorways via short flights of stairs. In the other image, the minarets remain the same, but the side and rear of the mosque have been extensively altered. The side entrances are now covered with a roofed colonnade and the rear has been remodeled. Similarly, the Din Agobera Mosque has been substantially rebuilt and has had the pillars removed that would have supported the original heavy flat roof of the type already described, as these were no longer needed to support the current corrugated iron roof (Zekaria 1979: 47). Visually, it has also changed rapidly with the addition of a textured coating and pink and red colour scheme in 2018 replacing the plain white and green paint recorded in 2017 (INSERT Figure 13). In addition to rebuilding, Horton (1994: 197) also suggests that 
earthquakes have been a factor affecting mosques, meaning that little original fabric survives and "no wall pre-dating 1800".

Comparable structures to the mosques of Harar, at least in their extant forms, are lacking. This is partly a reflection of the lack of research on Islamic archaeology in the Horn of Africa, particularly Ethiopia, as well as regional differences in mosque architecture (Insoll in press). However, a tradition of building mosques from stone slabs, either worked or unworked, bonded with earth mortar has been reported by archaeologists from across the region in parts of Somaliland, Djibouti, and Ethiopia. At Handoga, 10km west of Dikhil in Djibouti, a hexagonal structure built of square blocks of basalt set in mud mortar with a possible mihrab salient might have been a mosque. Two definite mosques were also recorded $2 \mathrm{~km}$ north-west of Handoga. One was an outline mosque formed of a row of stone slabs and the other built of square stone blocks (Grau 1976: 16). Handoga has been dated by two radiocarbon dates of the $14^{\text {th }}-15^{\text {th }}$ and $16^{\text {th }}$ centuries and two Arab coins, otherwise undescribed, of $11^{\text {th }}$ and $13^{\text {th }}$ century date (Gutherz 2013: 31-32).

A group of stone-built mosques have also been investigated in Shoa, north-eastern Ethiopia. At Nora a mosque measuring $13.2 \mathrm{~m} \times 12.2 \mathrm{~m}$, constructed of stone slabs was excavated and radiocarbon dated to Cal AD 1165-1298 (Fauvelle-Aymar et al. 2006a: 134; Fauvelle-Aymar and Hirsch 2010: 36). The walls were built into trenches cut in the bedrock to $20 \mathrm{~cm}$ depth with irregular blocks of local volcanic tuff used from the foundations upwards, except in the corners and mihrab where squared blocks of rhylolite had been employed (Fauvelle-Aymar et al. 2006b: 4-6) (INSERT Figure 14). The use of the same stone for foundations and walls and the differentiation of the cornerstones, as well as the almost square plan, varies from Harari mosque construction. Another mosque at Fäqi Däbbis has also been excavated. This appeared to have two phases of construction dated to Cal AD 1306-1426 and Cal AD 1402-1450. It was of rectangular plan measuring $17 \mathrm{~m} \times 14.35 \mathrm{~m} \times 16.35 \mathrm{~m} \times 14.30 \mathrm{~m}$. Two types of stone, basalt and limestone, had been used somewhat randomly to build the walls, but the pointed mihrab of $1 \mathrm{~m}$ depth was made from carefully cut blocks of limestone (Poissonnier et al. 2011: 115-130). A third standing mosque of unknown date at Goze was also recorded, which again differs from the Harar mosques. This is described as a stone cube $8 \mathrm{~m}$ long on each side and built of worked and unworked blocks of basalt. The roof was supported by four round wooden columns on stone bases. Beams ran from the columns and the framework was infilled with wooden planks, some decorated with low relief carved designs, to form a ceiling (Poissonnier et al. 2011: 106112).

Stone-built mosques are also found in the ruined settlements of Somaliland that connected the Red Sea coast with the Ethiopian interior (Mire 2015; González-Ruibal et al. 2017). The principal settlements of Amud, Abasa, Gogesa, and Au Bare were all situated at over 1000m and each had a mosque or mosques (Curle 1937). Some details of these structures are provided which indicate both similarities and differences with Harari mosques. The Abasa Mosque, for example, measured $18.2 \mathrm{~m}$ by $16.5 \mathrm{~m}$, i.e. approximately square, and thus differed from the rectangular Harari mosque plan. Another mosque at Rugayi was formed of a rectangular building with an open courtyard. Similarities also appear to exist in roofing techniques. These were probably of brushwood, laid on rafters and covered with earth (Curle 1937: 318). The roof of the Abasa mosque had been supported by 12 pillars. Of these, some had pieces of timber built into them about a metre from the ground, which Curle (1937: 319) suggests were for "the attachment of drapery or hangings". More likely is that these served a structural purpose perhaps analogous to the insertion of horizontal timbers into Harari mosque walls to prevent cracking, previously described. 
A ruined stone mosque was also excavated in Harlaa (Insoll 2017), which differs from the Harari mosques. The mosque plan was a short rectangle measuring approximately $970 \mathrm{~cm}$ length by $700 \mathrm{~cm}$ width but had a mihrab built of blocks of trimmed coralline limestone, with the walls constructed from larger less well-shaped blocks of basalt and limestone (INSERT Figure 15). The differentiation of the mihrab using limestone resembles that of Fäqi Däbbis, but the Harlaa mosque is not as well-finished. The Harlaa mosque was AMS dated to Cal AD 1155-1255 via a charcoal sample from the white lime mortar and gravel floor inside the building. A posthole suggested that the roof had been supported by wooden pillars rather than stone ones (Insoll, MacLean, and Engda 2016: 27), and as such was perhaps comparable to the mosque at Goze. The selective use of coralline limestone in the mihrab suggests coastal architectural influences (cf. Garlake 1966: 11). In the 'Mosque with Two Mihrabs' at Zeyla, for example, the first (undated) phase of the prayer hall was built with blocks of coralline limestone (Fauvelle-Aymar et al. 2011: 46). Whilst in the Kilwa region of southern Tanzania in the $11^{\text {th }}-12^{\text {th }}$ centuries, blocks of marine coral were used in construction, as in the first large mosque at Kilwa Kiswani (Pradines and Blanchard 2016: 14). Such coastal parallels are lacking in the Harari mosques.

South of Harlaa in the Bale region, only preliminary recording of mosque architecture has been completed at the important pilgrimage centre of Dirre Sheikh Hussein and in its surroundings. Sheikh Hussein is credited with bringing Islam to Bale, possibly in the $12^{\text {th }}$ century (Østebø 2012: 52). His mosque, the Zuqtum or Grand Mosque of Dirre Sheikh Hussein, is described as rectangular, measuring $27.75 \mathrm{~m} \times 22.35 \mathrm{~m}$, built of dry limestone with lime and mud mortar, and with 31 columns supporting a flat wooden roof covered with mud mortar. Inside there was a flight of stairs leading to the roof via an opening in the ceiling, i.e. a staircase minaret (Anon 2012: 28-29; Agizew and Abegaz 2015: 33). It is significant that parallels are drawn between the Dirre Sheikh Hussein complex and "Harari architecture" (Anon 2012: 16), as these do appear to exist in the rectangular plan, roof, and staircase minaret. This mosque replaced the mosque at Balla to the south (Agizew and Abegaz 2012: 29), which according to local sources, is of $11^{\text {th }}$ century date (Østebø 2012: 52). The Balla mosque clearly belongs to the same architectural tradition as the Harlaa and Nora mosques being built of similar shaped stone blocks (cf. Østebø 2012: Illustration 2). Three other dry stone-built mosques are also reported from the region, Sheikh Muhammad Tilma Tilmo, Sheikh Unero, and Sheikh Ibrahim (Agizew and Abegaz 2012: 30).

Thus, it is apparent that the mosques of Harar share some affinities with wider regional mosque architectural traditions primarily in the use of stone for construction, reflecting the paucity of other materials (Zekaria 1979). However, there are also differences in mosque plans, construction techniques, and materials with the closest parallels being with the Zuqtum Mosque at Dirre Sheikh Hussein.

\section{Conclusions}

The excavations indicate that all the mosques in Harar post-date the late $15^{\text {th }}$ century, and until evidence to the contrary is found, it is suggested that the city and its mosques date from this era and were linked with the establishment of Harar as the capital of Adal. The physical status of Harar was then made more concrete in a form that is still recognizable today through the building of the Djugel by Amir Nur. The seeming coterminous appearance of locally minted Harari coinage in the $16^{\text {th }}$ century (cf. Zekaria 1991) further suggests that this period was of 
particular significance in the city. Prior to this the Harari, likely in the form of the 'Harla', were elsewhere, possibly at the site of Harlaa or at one or more of the as yet uninvestigated abandoned stone town sites that are found across the eastern Harar Plateau and the Chercher Mountains (cf. Insoll 2017: 209-210). As such the oral traditions are likely correct that "Harar was founded by the remnants of Harala (Harla) people" (Zekaria 1979: 6), who then developed a Harari mosque architectural tradition that has affinities with its region but is also unique and as such reflects the status of the city as an autonomous and often self-contained polity.

\section{Acknowledgements}

Timothy Insoll is grateful to the Authority for Research and Conservation of Cultural Heritage (ARCCH), and particularly Ato Demrew Dagne, Ato Desalegn Ababew Andualem, and Ato Yonas Desta for giving permission to complete the archaeological research, and Mr Solomon Kebede and Ato Andualem for allowing the export of samples for analysis. He is also grateful to the staff of the Cultural Heritage Bureau in Harar, particularly Mr Muhammad Rabi, and the various mosque authorities in Harar for facilitating the fieldwork. He would also like to thank all the team members particularly Mr Misganaw Gebremikael, Antiquity Officer, ARCCH, Dr Nadia Khalaf, Dr Rachel MacLean, Mr Idris Hussein, Ms Hannah Parsons, and Mr Nicholas Tait, and Dr Rachel MacLean and Dr Nadia Khalaf for preparing some of the illustrations. Finally, the European Research Council is gratefully acknowledged for funding the fieldwork through the project "Becoming Muslim" (BM-694254-ERC-2015-AdG). Both authors thank Dr Rachel MacLean and two anonymous reviewers for commenting on the paper, though all errors and omissions remain their own.

\section{About the Authors}

Timothy Insoll is Al-Qasimi Professor of African and Islamic Archaeology in the Institute of Arab and Islamic Studies, University of Exeter, UK. He is currently Principal Investigator on a four-year archaeological research project in eastern Ethiopia funded by an Advanced Grant from the European Research Council (Becoming Muslim - 694254-ERC-2015-AdG). Previously, he has completed archaeological fieldwork in Bahrain, northern Ghana, Mali, and western India. He is the author or editor of 18 books and special journal issues and his most recent book (with S. Almahari and R. MacLean) is The Islamic Funerary Inscriptions of Bahrain, Pre-1317 AH/1900 AD (2018, Brill, Handbook of Oriental Studies Series).

Ahmed Zekaria is chief curator, with the rank of Assistant Professor, at Addis Ababa University, Institute of Ethiopian Studies. His main area of interest is south eastern Ethiopia. As professional museum expert, he served as Vice President of ARICOM for three years. He produced some publications related to history and heritage management, including of the Harar region, both in English and Amharic. He has completed some heritage identification survey work in Somali and Afar regions. Currently, he is engaged in researching the evolution of Ethiopic and Arabic scripts. 


\section{References}

Agizew, H., and Abegaz, M.

2012. Diree Sheik Hussein World Heritage Site Management Plan. Addis Ababa: Authority for Research and Conservation of Cultural Heritage.

Agizew, H., and Abegaz, M.

2015. The Dirre Sheikh Hussein Religious, Cultural and Historical Site Management Plan 2015-2021. Addis Ababa: Authority for Research and Conservation of Cultural Heritage.

Ahmed, A. M.

1990. "A Survey of the Harar Djugel (Wall) and its Gates." Journal of Ethiopian Studies 23: 321-34.

Anon.

2012. Dirre Sheikh Hussein Religious, Cultural and Historical Site World Heritage Nomination Dossier. Addis Ababa: Authority for Research and Conservation of Cultural Heritage.

Braukämper, U.

2004. Islamic History and Culture in Southern Ethiopia. Munster: Lit Verlag.

Burton, R.F.

1894 (1987). First Footsteps in East Africa or, An Exploration of Harar Volume 2. New York: Dover Publications.

Caulk, R.A.

1977. "Harär Town and Its Neighbours in the Nineteenth Century." Journal of African History 18: 369-386.

Cerulli, E.

1971 (2013). Islam Yesterday and Today. (Waber, E. M. trans.). Rome: Istituto per l'Oriente.

Chiari, G.P.

2015. A Comprehensive Guide to Harar and Surroundings. Addis Ababa: Arada Books.

CIRPS and Harari People National Regional State.

2003. Cultural Heritage of Harar. Mosques, Islamic Holy Graves, and Traditional Harari Houses. A Comprehensive Map. Rome: University of Rome.

Curle, A.T.

1937. "The Ruined Towns of Somaliland." Antiquity 11: 315-327.

Drewes, A.

1983. "The Library of Muhammad b. Ali b. Abd al-Sakur, Sultan of Harar." In Arabian and Islamic Studies, edited by R. Bidwell and G.R. Smith, 68-79. London: Longman.

Erlich, $\mathrm{H}$. 
1994. Ethiopia and the Middle East. London: Lynne Riener.

Fauvelle-Aymar, F-X., Hirsch, B., Bruxelles, L., Mesfin, C., Chekroun, A., and Ayenatchew, D.

2006a. "Reconnaissance de Trois Villes Museulmanes de l'Epoque Médiévale dans l'Ifat". Annales d'Ethiopie 22: 133-175.

Fauvelle-Aymar, F-X., Bruxelles, L., Chekroun, A., Mensan, R., Onézime, O., Wubete, A., Ayenatchew, D., Zeleke, H., Hirsch, B., and Mohamed, A.

2006b. "A Topographic Survey and Some Soundings at Nora, an Ancient Muslim Town of Ethiopia”. Journal of Ethiopian Studies 39: 1-11.

Fauvelle-Aymar, F-X., and Hirsch, B.

2010. "Muslim Historical Spaces in Ethiopia and the Horn of Africa: A Reassessment". Northeast African Studies 11: 25-53.

Fauvelle-Aymar, F-X., Hirsch, B., Bernard, R., and Champagne, F.

2011. "Le Port de Zeyla et son Arrière-pays au Moyen Âge". In Espaces Musulmans de la Corne de l'Afrique au Moyen Âge, edited by F-X. Fauvelle-Aymar and B. Hirsch, pp. 27-34. Paris: De Boccard.

Foucher, E.

1994. "The Cult of Muslim Saints in Harar: Religious Dimension." In Proceedings of the Eleventh International Conference of Ethiopian Studies, Volume 2, edited by B. Zewde, R. Pankhurst, and T. Beyene, pp. 71-83. Addis Ababa: Institute of Ethiopian Studies.

Garlake, P.

1966. The Early Islamic Architecture of the East African Coast. London: Oxford University Press.

Gibb, C.

2000. "Negotiating Social and Spiritual Worlds. The Gender of Sanctity in a Muslim City in Africa." Journal of Feminist Studies in Religion 16: 25-42.

González-Ruibal, A., de Torres, J., Franco, M. A., Ali, M. A., Shabelle, A. M., Barrio, C. M., and Aideed, K. A.

2017. "Exploring Long Distance Trade in Somaliland (AD 1000-1900): Preliminary Results from the 2015-2016 Field Seasons." Azania 52: 135-172.

Grau, R.

1981. “Handoga: Site d'Habitat de Pasteurs Nomades?” Archéologia 159: 55-59.

Gutherz, X.

2013. "L'Archéologie à Djibouti." In Djibouti Contemporain, edited by A. S. Chiré, 15-40. Paris: Karthala.

Harari People Regional State. 
2015. History of Harar and the Hararis. The Harari People Regional State Culture, Heritage, and Tourism Bureau.

Hecht, E-D.

1982. "The City of Harar and the Traditional Harar House." Journal of Ethiopian Studies 15: $56-78$.

Horton, M.

1994. "East Africa." In The Mosque, edited by M. Frishman and H-U. Khan, 194-207. London: Thames and Hudson.

Insoll, $\mathrm{T}$.

2003. The Archaeology of Islam in Sub-Saharan Africa. Cambridge: Cambridge University Press.

2017. "First Footsteps in the Archaeology of Harar." Journal of Islamic Archaeology 4: 189215.

Insoll, $\mathrm{T}$.

In Press. "The Islamic Archaeology of Ethiopia and the Horn of Africa". The Oxford Handbook of Islamic Archaeology, edited by B. Walker, T. Insoll, and C. Fenwick. Oxford: Oxford University Press.

Insoll, T. (ed.).

In Preparation. 'Becoming Muslim': The Archaeology of Harlaa, Harar, and Surrounding Region in Eastern Ethiopia. Leiden: Brill.

Insoll, T., Khalaf, N., MacLean, R., and Zerihun, D.

2017. "Archaeological Survey and Excavations, Harlaa, Dire Dawa, Ethiopia JanuaryFebruary 2017. A Preliminary Fieldwork Report.” Nyame Akuma 87: 32-38.

Insoll, T., MacLean, R., and Engda, B.

2016. "Archaeological Survey and Test Excavations, Harlaa, Dire Dawa, and Sofi, Harari Regional State, Ethiopia. A Preliminary Fieldwork Report." Nyame Akuma 85: 23-32.

Insoll, T. Tesfaye, H., and Mahmoud, M. S.

2014. "Archaeological Survey and Test Excavations, Harari Regional State, Ethiopia, JulyAugust 2014. A Preliminary Fieldwork Report.” Nyame Akuma 82: 100-109.

Mire, S.

2015a "Mapping the Archaeology of Somaliland: Religion, Art, Script, Time, Urbanism, Trade and Empire." African Archaeological Review 32: 111-36.

Østebø, T.

2012. Localising Salafism. Religious Change among Oromo Muslims in Bale, Ethiopia. Leiden: Brill.

Pankhurst, R.

1987. "The Manuscript Bindings of Harar. A Preliminary Examination.” Azania 22: 47-54. 
Paulitschke, P.

1888. Harar: Forschungreise nach den Somâl-und-Galla-ländern, Ost-Afrikas. Leipzig: F. A. Brockhaus.

Poissonnier, B., Ayenachew, D., Bernard, R., and Hirsch, B.

2011. "Les Mosquées Médiévales de Goze et Fäqi Däbbis (Ifat)". In Espaces Musulmans de la Corne de l'Afrique au Moyen Âge, edited by F-X. Fauvelle-Aymar and B. Hirsch, pp. 103-139. Paris: De Boccard.

Pradines, S. and Blanchard, P.

2016. "Songo Mnara. Étude Architecturale d'une Ville Swahilie Médiévale”. Taarifa 5: 9-33.

Santelli, S.

2008. "Harar: The Fourth Holy City of Islam." In The City in the Islamic World, Volume 1, edited by S.K. Jayyusi, 625-641. Leiden: Brill.

Stenhouse, P. (trans.).

2003. Futuh al-Habasa. Hollywood (CA): Tsehai.

Tesfaye, $\mathrm{H}$.

2011. Short Descriptions of Archaeological Sites in and around Harar. Unpublished Report. ARCCH, Addis Ababa.

Wagner, E.

1973. "Eine Liste der Heiligen von Harar." Zeitschrift der Deutschen Morgenländischen Gesellschaft 123: 269-292.

Wagner, E.

1974. "Three Arabic Documents on the History of Harar." Journal of Ethiopian Studies 12: 213-224.

Waldron, S.R.

1978. "Harar: The Muslim City in Ethiopia." In Proceedings of the $5^{\text {th }}$ International Conference on Ethiopian Studies, edited by R.L. Hess, 239-257. Chicago: University of Illinois at Chicago Circle.

Wilding, R.

1976. "Harari Domestic Architecture." Art and Archaeology Research Papers 9: 31-7.

Wilding, R. 1980. "The Desert Trade of Eastern Ethiopia". In Proceedings of the $8^{\text {th }}$ Panafrican Congress, edited by R. E. Leakey and B. A. Ogot, 379-380. Nairobi: Louis Leakey Institute.

Zekaria, A.

1979. The Mosques of Harar. Unpublished Dissertation. Institute of Ethiopian Studies, Addis Ababa University.

1987. "Some Notes on the Account-Book of Amīr 'Abd Al-Shakūr b. Yūsuf (1783-1794) of Harar." Sudanic Africa 8: 17-36.

2001. "Harari Coins: A Preliminary Survey". Journal of Ethiopian Studies 24: 23-46. 
2003. "Some Remarks on the Shrines of Harar." In Saints, Biographies and History in Africa, edited by B. Hirsch and M. Kropp, 19-29. Frankfurt AM: Peter Lang.

\section{Web References}

1. https://nationalcementsc.com/about.php (accessed 12/8/18) 


\section{Tables}

1. Mosques excavated in Harar

2. Table 2. Accelerator Mass Spectrometry radiocarbon dates from the Harar mosque excavations

3. Archaeological material from the Harar mosques

\section{Figures}

1. The location of Harar in Ethiopia (drawn by N. Khalaf)

2. The locations of the mosques and other sites previously excavated in Harar (drawn by N. Khalaf)

3. Right of doorway, staircase minaret on the Aw Abadir Mosque (photo. T. Insoll)

4. Plan of the Jami Mosque (after Zekaria 1979: 53-55 and Horton 1994: 197)

5. Figure 5. Left. ABD 18 (A) at the end of excavation. The external wall of the mosque compound is at the rear. Right. The free-standing minaret at the Aw Abdel Mosque (photos. T. Insoll)

6. The two pits at AWAB 18 (A) (photo. T. Insoll)

7. Top left. AWM 18 (A) at the end of excavation. Top right. AWM 18 (B) at the end of excavation. The soak-way and drain gulley are in the lower section. Bottom left. Base of the formerly free-standing minaret, Aw Meshad Mosque. Bottom right. Aw Meshad mosque (photos. T. Insoll)

8. DIN 18 (A). Left, the unit with stone layer in-situ. Right, the burial (photos. T. Insoll)

9. Top. Exterior of the Fehkredine Mosque. Bottom left. FAK 18 (A). Modern rubbish deposits surrounding the pit. Bottom right. FAK 18 (B). Concrete steps (photos. T. Insoll)

10. JAM 18 (A). End of excavations with modern pit cutting into earlier deposits (photo. T. Insoll)

11. Top left. Representative locally manufactured ceramics. Top right. Chinese blue and white ware (FAK 18 [A] 3). Bottom left. Middle Eastern glazed ware (DIN 18 [A] 5). Bottom right. Middle Eastern glazed ware (AWAB 18 [A] 2) (photos. T. Insoll)

12. The Jami Mosque before (left) and after (right) re-modelling (Insoll collection)

13. Din Agobera Mosque in February 2017 and February 2018 (photos. T. Insoll)

14. Left. Exterior of the mosque at Nora. Right. Interior of the mosque at Nora showing mihrab and one of the columns that would have supported the roof (photos. T. Insoll) 
15. The mosque at Harlaa. The mihrab is on the left and posthole, possibly for a wooden column, in the foreground (photo. T. Insoll) 